\title{
Determinants of Commercial Bank Profitability: South Asian Evidence
}

\author{
Shrimal Perera \\ Monash University, Caulfield East, Victoria 3145 Australia \\ Michael Skully \\ Monash University, Caulfield East, Victoria 3145 Australia \\ Zahida Chaudhry \\ Monash University, Caulfield East, Victoria 3145 Australia
}

Received: Jan 7, 2013 Accepted: March 19, 2013 Published: June 1, 2013

doi:10.5296/ajfa.v5i1.3012 URL: http://dx.doi.org/10.5296/ajfa.v5i1.3012

\begin{abstract}
This study investigates the bank-specific and other determinants of commercial bank profitability in selected South Asian countries (Bangladesh, India, Pakistan and Sri Lanka). The single-equation, dynamic panel data procedure employed accommodates explicit measures of production efficiency, industry competition, profit persistence and country-specific differences in governance. The findings reveal profit persistence in South Asian banking markets. Even though increasing competition exerts negative pressure on bank profitability, high industry concentration still allows these banks to earn higher profits. The well-capitalised banks and those with relatively more efficient production processes are the more profitable. South Asian banks also seem to experience economies of scale as bank size is positively associated with profitability. The results also indicate that slack legal systems in these countries (leading to inferior contract enforcement) positively affect profits as banks probably require higher risk premiums on their loan contracts.
\end{abstract}

Keywords: Bank profitability, competition, profit persistence, South Asia, banking 


\section{Introduction}

South Asian financial markets are in transition as deregulation and liberalization measures stimulate and facilitate greater competition, improve operational transparency, streamline regulatory policies and achieve higher efficiency levels (Central Bank of Sri Lanka 2009; Bangladesh Bank 2009). In addition, the South Asian Association for Regional Cooperation (SAARC) and its South Asian Free Trade Agreement (SAFTA) seeks more cross-border trade and competition in financial services. This objective is reinforced further by a range of bilateral trade agreements affording even greater access between South Asian financial markets.

While these regional efforts concentrated mainly on the local to local access, international players are also gaining greater access through the General Agreement on Trade in Services (GATS). The GATS require its members ensure 'level playing fields' in financial services by removing discriminatory policies against foreign banks, thus further exposing the 'protected' South Asian domestic banks to new competitive dynamics and banking strategies. Moreover, South Asian governments must also respond to other regulatory changes within the increasingly 'globalizing' financial markets. These include the Basel Accord capital adequacy requirements, international accounting and auditing standards and practices, and self regulation and market discipline etc.

Such level of change within the region offers a rich basis for inquiry into the competitive dynamics, efficiency and profitability of South Asian banking systems. Some prior studies have examined the factors affecting competitive dynamics and bank production efficiency in isolation ignoring their impact on bank earnings and profitability (see, Perera, Skully and Wickremanayake 2006 and Perera, Skully and Wickremanayake 2007). They provide no direct insights, however, into the determinants of South Asian bank profitability given changes in bank competition and efficiency. Thus, we are motivated to investigate these determinants as only sound and profitable banking sectors can endure negative shocks and contribute to stability of financial systems and economic growth.

Specifically, the following research question is addressed: What bank-specific and external factors drive South Asian bank profitability? Our sample comprises of 119 domestic commercial banks in four selected South Asian countries (Bangladesh, India, Pakistan and Sri Lanka) over 1992-2007 with 1,539 bank-year observations. We utilise a single-equation, dynamic panel data procedure which accommodates explicit measures of production efficiency, industry competition, profit persistence and country-specific differences in governance.

We contribute to the literature in several ways. As far as it could be ascertained, this is the first study to accommodate possible profit persistence (given the high level of concentration in South Asian banking markets) and for cross-country differences in corruption and rule of law. Our model also includes an industry competition measure derived from bank-specific revenue behaviour (Panzar-Rosse $H$ statistic) to control for competitive dynamics. Finally, we utilise an explicit measure of management efficiency in the form of data envelopment analysis (DEA) efficiency scores in our analyses. This approach provides more reliable 
management efficiency estimates than the expense ratios of prior bank profitability studies.

\section{Literature review}

\subsection{Bank-specific determinants}

The prior bank profitability literature employs bank size, ownership status, bank risk, capital level, and expense management as bank-specific determinants. Bank size is generally found to relate positively to profitability (Kosmidou 2008). This supports the argument that large banks typically benefit from scale and scope economies and have greater product and loan diversification leading to lower risk profiles. Hence, their required rate of return becomes lower which reduces their costs and generates higher profits. Large banks may also be able to exert market power through stronger brand image or implicit regulatory (too-big-to-fail) protection. Abnormal profits obtained through the exercise of market power in wholesale or capital markets may also contribute to a positive size-profitability relationship (Goddard, Molyneux and Wilson 2004). In contrast, if bank size is a function of 'empire building' by managers and/or government-sponsored funding (especially in developing countries like those in South Asia), then the resulting diseconomies should lead to a negative association between bank size and profitability. Thus, no a priori expectation is formed with regard to bank size in the South Asian context.

Ownership status is primarily concerned with whether a bank is government- or privately owned. Generally, privately-owned firms generate relatively higher profits (see for example, Kosmidou, Pasiouras and Tsaklanganos 2007). This is consistent with the view that government-owned banks may have other than simply profit considerations. It is especially true in developing countries (like those in South Asia), where loan distribution is influenced by government directed credit programmes, interest rate ceilings and branching restrictions. Thus, we expect the privately-owned South Asian banks to be relatively more profitable than their government-owned counterparts.

Bank risk is conceptualised in the literature using proxies for credit risk and liquidity risk. The former is generally negatively related to profitability since financial institutions exposed to more high-risk loans accumulate more non-performing loans (Miller and Noulas 1997). With liquidity, since liquid assets have lower risk and generate lower returns, these holdings earn less than could be otherwise gained from higher risk, less liquid assets. In this way, higher level of liquid holdings reduces profits (Molyneux and Thornton 1992). Thus, we expect South Asian banks will show a negative relationship between credit risk and bank profitability and a positive relationship between liquidity risk and bank profitability.

Bank capital level is another important determinant of bank profitability. The well-capitalised banks should attract deposits at lower cost thereby increasing their profitability. This association is reported by several studies (see Molyneux and Thornton 1992; Demirguc-Kunt and Huizinga 1999; Athanasoglou, Brissimis and Delis 2008). Thus, a positive relationship is expected between South Asian banks' capital level and profitability. 
The expense management ratios, as proxies for management quality, have also been used in bank profitability studies. Athanasoglou, Brissimis and Delis (2008) separate the total cost of banks (net of interest payments) into operating cost and other expenses (including taxes, depreciation etc.). They argue that only operating expenses are an outcome of bank management. The ratio of these expenses to total assets should be expected to be negatively related to profitability, since their better management may increase efficiency and therefore raise profits. This applies in particular to banking markets (like those in South Asia) where personnel expenses are affected by relatively low productivity and the excess capacity of the larger publicly-owned banks. Hence, a positive relationship is expected between management efficiency and bank profitability in South Asia.

\subsection{Industry-specific determinants}

The market structure (and the number and size distribution of competitors) also influences bank profitability. For example, when competition is weak in concentrated markets, firms may acquire monopoly profits by using their market power to charge higher loan prices and offer lower deposit rates. So increased concentration is not the result of managerial efficiency, but rather reflects increasing deviations from competitive market structures, which lead to monopolistic profits. Consequently, concentration should be positively related to bank profitability. Studies that examine this relationship reach inconsistent results. For example, on the one hand, Gilbert's (1984) review identifies 27 prior studies that provide evidence that banks in highly concentrated markets tend to collude and earn monopoly profits. On the other hand, Kosmidou (2008) finds industry concentration to be statistically significant but negatively related to bank profits. Their implication is that increased industry concentration leads to slack operational efficiency and so reduced profitability. Due to the contradictory evidence, no a priori expectation is formed with regard to the relationship between bank market concentration and profitability.

\subsection{Country-specific determinants}

In addition to these bank specific variables, the literature also has identified other factors important in this relationship such as macro-economic variables and the corruption and rule of law indicators. The macro-economic variables employed (the inflation rate, the long-term interest rate and/or the growth rate of money supply) were found to have a positive relationship with bank profitability (Molyneux and Thornton 1992). With regard to the corruption and rule of law, banks operating in environments characterised by high levels of law and order and corruption controls earned lower interest margins possibly reflecting lower risk premiums required on bank lending (Demirguc-Kunt and Huizinga 1999). In the South Asian context, the expected relationships between macroeconomic variables and bank profitability and law and order/corruption controls and profitability should be consistent with the existing evidence.

\section{Data and method}

This study utilises unconsolidated, bank-specific annual data of 119 domestic commercial banks operating in four South Asian countries (Bangladesh, India Pakistan, Sri Lanka). 
Unconsolidated data is preferred over the consolidated data as the latter includes revenue and costs from non-bank subsidiaries of bank holding companies. Sample and sample period are constrained by the data availability. For example, other South Asian countries - Bhutan, Maldives and Nepal - are excluded due to data limitations. Other types of banks, such as investment banks, saving banks, cooperatives banks and non-bank financial intermediaries (insurance companies, mortgage houses etc.) are excluded as their regulatory requirements differ from those for commercial banks.

The primary source of bank-specific annual data is the Bankscope database. Data for corruption control and law and order are obtained from the governance indicators published in a World Bank's policy research paper by Kaufmann, Kraay and Mastruzzi (2007). These aggregate indicators are based on hundreds of specific and disaggregated individual variables measuring various dimensions of governance, taken from 33 data sources provided by 30 different organizations. The data reflect the views on governance of public sector, private sector and NGO experts, as well as thousands of citizen and firm survey respondents worldwide. As explained later in this section, competition indicators (the $H$ statistics and the Herfindahl-Hirschman Index (HHI) values) and bank-specific efficiency measures (based on data envelopment analysis (DEA)) are computed by the authors.

With regard to sampling procedure, a comprehensive list of 198 licensed commercial banks was initially obtained from the central bank annual reports of Bangladesh, India, Pakistan and Sri Lanka. (A summary of the sampling procedure is given in Table 1). These were then searched in the BANKSCOPE database for bank-specific information. Due to data limitations, 70 foreign bank subsidiaries and branches and 8 domestic commercial banks (5 Bangladeshi, 3 Pakistani and 1 Indian) were eliminated resulting in 119 banks. This represents the overall domestic banking markets of the four countries with 94 percent coverage. Of the 119 bank final sample, there are 29 Bangladeshi, 58 Indian, 21 Pakistani and 11 Sri Lankan banks. The high proportion of Indian banks reflects the large number of domestic banks in India.

Table 1. Sampling procedure and sample size

\begin{tabular}{lr}
\hline Description & No. \\
\hline Licensed commercial banks in Bangladesh, India, Pakistan and Sri Lanka (July 2008) & 198 \\
Exclude: Foreign subsidiaries and branches (annual statements not published) & 70 \\
\hline Total Number of domestic commercial banks & 128 \\
Exclude: Banks not covered in the Bankscope database & 9 \\
\hline Final sample (Number of banks) & $\mathbf{1 1 9}$ \\
Total bank-year observations over 1992-2007 & $\mathbf{1 , 5 3 9}$ \\
\hline
\end{tabular}

The sample's coverage of each banking market (based on ratio of total assets of sample banks to total assets of the banking sector) is shown in Table 2 and varies from a low of 60 percent in Pakistan to a high of 83 percent in Sri Lanka. In terms of ownership, 69 percent of the sample is private-owned and 31 percent is government-owned. There are 76 listed and 44 
non-listed banks in the sample. With regard to number of observations, the final sample consists of 1,539 bank-year observations over 1992-2007.

Table 2. Domicile of sample banks and composition

\begin{tabular}{lccccc}
\hline & & Bangladesh & India & Pakistan & Sri Lanka \\
\hline $\begin{array}{l}\text { No. of sample banks } \\
\text { domestic banks (\%) }\end{array}$ & 85.3 & 98.3 & 87.5 & 100 \\
\hline $\begin{array}{l}\text { Of sample banks } \\
\text { State-owned }\end{array}$ & 4 & 27 & 3 & 2 \\
Private-owned & 25 & 31 & 18 & 9 \\
\hline Listed & 15 & 39 & 16 & 6 \\
$\quad$ Non-listed & 14 & 19 & 5 & 5 \\
\hline Share of assets (\%) & & & & \\
\hline
\end{tabular}

${ }^{a}$ ratio of total assets of sample banks to total assets of the banking sector.

Sources: Bankscope data base, annual reports from respective central banks

This study specifies a single-equation dynamic panel model which controls for competitive dynamics in the South Asian banking markets and country-specific differences in regulatory and governance structures. The Generalized Method of Moments (GMM) estimators help to account for possible correlations among independent variables (Baltagi 2001; Athanasoglou, Brissimis and Delis 2008). The general model used takes the following form:

$$
\pi_{i t}=\mathrm{c}+\sum_{f=1}^{F} \beta_{f} X_{i t}^{f}+\beta_{Y} Y_{j t}+\sum_{m=1}^{M} \beta_{m} Z_{j t}^{m}+\sum_{\mathrm{t}=1}^{T-1} \beta_{t} D_{t}+\varepsilon_{i t}, \quad \varepsilon_{\mathrm{it}}=\mathrm{v}_{\mathrm{i}}+\mathrm{u}_{\mathrm{it}},
$$

where $i$ denotes banks, $t$ time, $j$ countries, $X^{\prime}$ bank-specific factors, $Y$ industry structure, $Z^{m}$ macroeconomic factors and $D$ a vector of time dummies. $\pi$ is the profitability of bank, $\varepsilon$ is the disturbance, with $v$ the unobserved bank-specific effect and $u$ the idiosyncratic error. This is a one-way error component regression model, where $v_{i} \sim \operatorname{IIN}\left(0, \sigma_{v}^{2}\right)$ and independent of $\operatorname{IIN}(0$, $\sigma_{v}^{2}$ ). Bank profits show a tendency to persist over time reflecting impediments to market competition, informational opacity and/or sensitivity to regional/macroeconomic shocks to the extent that these are serially correlated (Berger et al. 2000). Hence, a dynamic specification of Equation 1 is utilised by including a lagged dependent variable among the regressors to account for profit persistency as follows:

$$
\pi_{i t}=\mathrm{c}+\delta \pi_{i, t-1}+\sum_{\mathrm{f}=1}^{\mathrm{F}} \beta_{f} X_{i t}^{f}+\beta_{Y} Y_{j t}+\sum_{m=1}^{M} \beta_{m} Z_{j t}^{m}+\sum_{\mathrm{t}=1}^{T-1} \beta_{t} D_{t}+\varepsilon_{i t},
$$

where $\pi_{i, t-1}$ is the one-period lagged profitability and $\delta$ is the speed of adjustment to equilibrium. If $\delta$ takes a value close to 0 , it means that industry has high speed of adjustment to equilibrium while a value of $\delta$ close to 1 implies very slow adjustment to equilibrium. 
For empirical investigation, Equation (2) is expanded as follows:

$$
\begin{aligned}
R O A A_{i t}=\mathrm{c}+\delta R O A_{i, t-1}+ & \beta_{E Q} E Q_{i t}+\beta_{L I Q} R I S K_{i t}+\beta_{T E C} E F F_{i t}+\beta_{T A} T A S S E T S_{i t}+\beta_{C O M P} C_{\text {COMP }}+ \\
& \beta_{R O L} R_{i t}+ \\
\text { it } & +\beta_{\text {CORR }} \operatorname{CORR}_{i t}+\beta_{T A X} T A X_{i t}+\sum_{t=1}^{T-1} \beta_{t} D_{t}+\varepsilon
\end{aligned}
$$

where subscript $R O A A$ denotes bank profitability, $E Q$ bank equity capital, RISK bank liquidity ratio, EFF technical efficiency, TASSETS bank size, COMP industry competition, $R O L$ rule of law, CORR control of corruption and TAX represents tax rate. These variable definitions, summarised in Table 3, are now each discussed separately.

\begin{tabular}{|c|c|c|}
\hline Variables & Definitions & Supporting Literature \\
\hline \multirow[t]{2}{*}{ ROAA } & The return on average total assets & Pasiouras and Kosmidou (2007); \\
\hline & & Athanasoglou, Brissimis and Delis (2008) \\
\hline EQ & Equity per dollar of total assets & $\begin{array}{l}\text { Molyneux and Thornton (1992); Pasiouras } \\
\text { and Kosmidou (2007); Athanasoglou, } \\
\text { Brissimis and Delis (2008) }\end{array}$ \\
\hline RISK & $\begin{array}{l}\text { Loans per dollar of deposits and } \\
\text { short-term funds }\end{array}$ & $\begin{array}{l}\text { Pasiouras and Kosmidou (2007); Kosmidou } \\
\text { (2008) }\end{array}$ \\
\hline EFF & DEA technical efficiency scores & $\begin{array}{l}\text { Charnes et al., (1978); Nakane and } \\
\text { Weintraub (2005); Yi-Hsing et al., } 2007\end{array}$ \\
\hline COMP & $\begin{array}{l}H \text { statistic / Herfindahl-Hirschman } \\
\text { Index }(H H I)\end{array}$ & $\begin{array}{l}\text { Panzar and Rosse (1987); Bikker and Haaf } \\
\text { (2002) }\end{array}$ \\
\hline ROL & The Rule of Law Index & Kaufmann, Kraay and Mastruzzi (2007) \\
\hline CORR & The Control of Corruption Index & Kaufmann, Kraay and Mastruzzi (2007) \\
\hline TAX & Tax paid on profit before tax & Demirguc-Kunt and Huizinga (1999) \\
\hline
\end{tabular}

Table 3. Variable definitions

With regard to the independent variable, i.e., ROAA, we employ average value of assets rather than end-year values in order to avoid possible use of window dressing techniques as profits are a flow variable generated during the year. The use of average assets values is found to be more reliable measure of profitability as it captures any differences that occurred in assets during the fiscal year (Athanasoglou, Brissimis and Delis 2008).

The ratio of equity to total assets ( $E Q$ in Equation 3) is used as the proxy for a bank's capital strength. Banks with higher capital-assets ratios have low levels of leverage and therefore, less risk. This reduces cost of capital for the bank and increases its profitability. Hence, a positive coefficient for $E Q$ variable is expected.

The ratio of loans to deposits and short term funding (RISK in Equation 3) is used as the proxy for banking risk (Pasiouras and Kosmidou 2007 and Kosmidou 2008). In fact, this ratio captures both credit risk and liquidity risk and affects profitability in multiple ways. For 
example, higher values for loans to deposits and short term funding ratio signify (1) more funds invested in earning assets and higher expected profitability, (2) lower holdings of liquid assets and lower expected profitability due to increased costs of purchased funds as an alternative, and (3) lower profitability due to increased credit risk and loan losses. Thus, no a priori expectation is made about the sign of the RISK variable.

Management efficiency (represented by EFF in Equation 3) is measured using bank-specific technical efficiency scores computed using nonparametric data envelopment analysis (DEA). Our approach is consistent with Berger and Humphrey (1997) who profess that frontier-based efficiency scores provide more reliable management efficiency measures. Moreover, the expense ratios used in prior bank profitability studies suffer bias due to accounting adjustments. In the DEA algorithms, consistent with the intermediation approach, banks are viewed as combining deposits and equity capital to generate net total loans and other earning assets. With regard to input-output orientation, we recognise that profit maximisation requires a bank to produce the maximum output given the level of inputs employed (i.e., be technically efficient). Since, profitability improves when banks become more efficient a positive coefficient for EFF variable is expected (Berger, Hancock and Humphrey 1993).

Bank size (TASSETS) is utilised in Equation 3 to control for scale effects. Insofar large banks exert market power through stronger brand image or implicit regulatory (too-big-to-fail) protection a positive coefficient for TASSETS variable is expected. In contrast, a negative coefficient is expected if bank size is a function of 'empire building' by managers and/or government-sponsored funding programmes.

Bank competition (represented by COMP in Equation 3) is measured using the $H$-statistics derived from the non-structural Panzar and Rosse (PR) model (Panzar and Rosse 1987). This approach recognises that competition could be present in markets characterised by relatively high degree of concentration. Using the PR model, the competitive indicator, $H$ statistic, can be defined as the sum of elasticities of the reduced-form revenues with respect to input prices (indexed by $k$ ). Market power is assessed by the extent to which a change in input prices $\left(\partial w_{k i}\right)$ is reflected in the revenues earned by bank $i\left(\partial R_{i}\right)$. Thus $H$ statistic is defined as:

$$
H=\sum \frac{\partial R_{i}^{*} w_{k i}}{\partial w_{k i} R_{i}^{*}}
$$

Panzar and Rosse (1987) establish that $H$ statistic is an increasing function of the demand elasticity, $e$, and hence there is a negative relationship between the level of market power exercised by the firms and the value of $H$. In other words, higher $H$ values represent more competitive markets and lack or market power at firm level and vice versa. This proposition highlights the explanatory power of $H$ as an indicator of level of competition. Following Bikker and Haaf (2002) procedure, $H$ statistics for the sample countries are obtained and employed in Equation 3 as the proxy for industry competition. Since higher values of the $H$ statistic represents greater competition levels a negative coefficient for COMP variable is expected.

To verify the robustness, we also utilise Herfindahl-Hirschman Index $(H H I)$ as an alternative 
measure of bank competition (represented by COMP in Equation 3). The HHI is a measure of the size of firms in relationship to the industry and an indicator of the amount of competition among them. It is defined as the sum of the squares of the market shares of each individual firm (i.e., the average market share) weighted by market share and expressed as:

$$
H H I=\sum_{i=1}^{n} S_{i}^{2}
$$

Here $S_{i}^{2}$ is square of the market share of each firm " $i$ ". Value for $H H I$ can range from 0 to 1 moving from a very large amount of very small firms to a single monopolistic producer, i.e., if a market is closer to being a monopoly and the market's concentration is higher (and the lower its competition) the value is closer to one. Similarly, if there is large number of small firms competing, each would have nearly zero percent market share, and the $H H I$ would be close to zero indicating nearly perfect competition. Hence, decreases in the Herfindahl Index generally indicate a loss of pricing power and an increase in competition, whereas increases imply the opposite (Bikker and Haaf 2002). To the extent increasing competition exerts downward pressure on profitability a negative coefficient is expected for $H H I$.

In addition to bank-specific factors and industry competition, other differences across countries may also need to be considered. In particular, corruption and law and order in developing countries (e.g. South Asian countries) may be important in determining bank profitability. For example, not only international investments are affected by a country's state of law and order, but domestic businesses also suffer if state fails to enforce the contracts due to corruption. Thus, we utilize two governance indicators calculated by Kaufmann, Kraay and Mastruzzi (2007) and published by the World Bank: the Rule of Law Index $(R O L)$ and the Control of Corruption Index $(C O R R)$. These indicators are reported on a scale of -2.5 to +2.5 with higher values indicating good quality rule of law/corruption controls. As the prevalence of rule of law and effective corruption controls ensures a conducive environment and quality of contract enforcement, positive coefficients are expected for $R O L$ and CORR variables.

Furthermore, following Demirguc-Kunt and Huizinga (1999) we utilise bank-specific tax rate (TAX variable in Equation 3) to control for differing tax regimes and treatments among sample firms. Taxes are expected to increase bank revenue insofar a bank is able to shift its tax bill forward to its depositors and lenders. This is supported by the common observation that bank-stock investors need to receive a net of company tax return that is independent of the company tax. This relationship is tested by Demirguc-Kunt and Huizinga (1999) and it is found that corporate tax is positively associated with bank profitability. Hence, a positive coefficient for $T A X$ variable is expected.

Finally, this study uses annual cross-section and time series pooled data as this helps to remove biases caused by aggregating heterogeneous individual banks. This approach also provides more reliable regression estimates due to the larger sample size and helps to control for any unobserved heterogeneity / omitted variable problems. In a strictly time series or cross section approach, these may be absorbed into the usual error term and can cause problems in estimation (Baltagi 2001). 


\section{Results}

\subsection{Summary statistics of the data set and econometric issues}

The summary statistics for the data set are given in Table 4. Not surprisingly, the TASSETS shows the largest variation and highlights the wider dispersion of bank size in the sample. Similarly, bank competition (represented by COMP) measured in terms of the $H$ statistic varies considerably over the sample period possibly signifying the effect of deregulation and financial liberalization measures taken by the South Asian governments. The average level of competition $(H$ statistic $=0.7314)$ is consistent with the findings of Perera, Skully and Wickremanayake (2006) who report $H$ statistics for the same four banking market over 1995-2003. The efficiency ratio ( $E F F$ variable) implies that on average South Asian banks could have increased their output by approximately 10 percent given the respective input levels. Perera, Skully and Wickremanayake (2007) report a possible efficiency improvement ratio of 12 percent for the same banking markets over 1997-2004.

Table 4. Summary statistics of the data set

\begin{tabular}{lllll}
\hline Variable & Mean & Maximum & Minimum & Std. dev. \\
\hline ROAA & 0.0097 & 0.1024 & -0.1820 & 0.0178 \\
$C O M P$ & 0.7314 & 1.2047 & 0.1300 & .3567 \\
$E Q$ & 0.0593 & 0.9931 & -0.0679 & 0.0774 \\
$C O R R$ & -0.5600 & -0.1300 & -1.3200 & 0.3285 \\
RISK & 0.5830 & 3.2972 & 0.0609 & 0.1816 \\
ROL & -0.2414 & 0.2900 & -0.9500 & 0.4649 \\
TAX & 0.2725 & 0.5274 & -3.1900 & 6.4933 \\
TASSETS & $\mathrm{US} \$ 3.3 \mathrm{~m}$ & $\mathrm{US} \$ 1300 \mathrm{~m}$ & $\mathrm{US} \$ 0.3 \mathrm{~m}$ & $\mathrm{US} \$ 8.6 \mathrm{~m}$ \\
EFF & 0.9370 & 1.0000 & 0.1914 & 0.0910 \\
\hline
\end{tabular}

$R O A A$ - The return on average total assets; COMP - H statistics; $E Q$ - Equity per dollar of total assets; CORR - the Control of Corruption Index; RISK - Loans per dollar of deposits and short-term funds; $R O L$ the Rule of Law Index; TAX - Tax paid on profit before tax; TASSETS - total assets; EFF - DEA technical efficiency scores.

The risk profile of the sample banks (RISK) is also diverse with the average ratio of loans to deposits and short-term funding of 58 percent but with a minimum of just 6 percent. This is in line with the $E Q$ variable measuring equity capitalization as the ratio of total equity to total assets with a maximum value of 99 percent. The Rule of Law Index and the Control of Corruption Index (which varies between -2.5 and +2.5) show the lowest variation and signifies little improvement over the sample period.

With regard to the methodology, our relatively larger time period $T,(T=15)$, may lead to issues regarding non-stationarity of the panel. This is evaluated by using Fisher test and null hypothesis of non-stationarity is rejected at the 5 percent level. Maddala and Wu (1999) 
suggest the use of the Fisher test, which is based on combining the $p$-values of the test statistic for a unit root in each bank. The advantage of this test is that not only it performs better than other tests for unit roots in panel data but also it can work with unbalanced panels. Prior to obtaining empirical results, we also established whether the difference in coefficients between fixed effects (FE) and random effects (RE) is systematic or not. Hausman test is used for this purpose and as the test statistic indicates, differences are found to be systematic providing evidence in favour the FE model $\left(X^{2}(9)=35\right)$.

With regard to extracting consistent and efficient estimates, we used all available lagged values of the dependent variable plus lagged values of the exogenous regressors as instruments (Arellano and Bond 1991). The use of the Arellano and Bond estimator has been criticized sometimes when applied to panels with very small time periods. The reason suggested is that under such conditions this estimator is inefficient if the instruments used are weak (Arellano and Bover 1995). In this study however, the $T$ is 15 , which is arguably large enough to avoid such problems. Consequently, the model can be safely estimated using the GMM estimator in the Arellano and Bond paradigm. The Sargan test indicates that there is no evidence of over-identifying restrictions, model is correctly specified and instruments are valid $\left(X^{2}(106)=274.61\right)$. Although the equations indicate the presence of negative first-order autocorrelation $(\mathrm{z}=-13.79$, $\mathrm{p}$-value $=0.0001)$ this does not imply that the estimates are inconsistent. Estimates are considered inconsistent if second order autocorrelation is present (Arellano and Bond, 1991), but this case is rejected by the test for AR (2) errors $(\mathrm{z}=1.52$, $\mathrm{p}$-value $=0.13)$. Finally, because the time frame of this study is fairly large $(T=15)$ and due to the developments and regulatory changes in the South Asian banking markets, time effects can be present in the error component of the model. This issue is addressed by testing for each year and using a vector of dummies to capture time-varying effects.

\subsection{Discussion of findings}

Overall, the coefficients' signs and statistical significance are consistent and there is broad stability across Model 1 and Model 2. This indicates the relative soundness of model fitting and the reliability of the estimates obtained. The main results are now discussed in the same order as presented in Table 5. The highly significant coefficient for the lagged profitability variable $(R O A A(-1))$ confirms the dynamic character of the model specification. Its coefficients take values of 0.2352 in Model 1 and 0.1564 in Model 2 which reveal that speed of adjustment is slow and that profits seem to persist to a moderate extent. Athanasoglou, Brissimis and Delis (2008) reported similar findings.

The equity capital level $(E Q)$, as anticipated, is found to be significantly and positively associated with bank profitability. These results substantiate the fact that well-capitalised banks can source deposits and other funding at low cost and thereby increase their profits. Similar results are presented by Pasiouras and Kosmidou (2007) and Athanasoglou, Brissimis and Delis (2008). 
Table 5. GMM estimates

\begin{tabular}{|c|c|c|c|c|}
\hline Panel A: Regression results & \multicolumn{2}{|c|}{$\begin{array}{c}\text { Model } 1 \\
\text { (with the } H \text {-statistic) }\end{array}$} & \multicolumn{2}{|c|}{$\begin{array}{c}\text { Model } 2 \\
\text { (with the HHI) }\end{array}$} \\
\hline Variables (proxy) & Coefficient & $p$-values & Coefficient & $p$-values \\
\hline Lag profitability $(R O A A(-1))$ & 0.2352 & $0.0061 * *$ & 0.1564 & $0.0278^{* *}$ \\
\hline Equity capital level $(E Q)$ & 0.0704 & $0.0078 * *$ & 0.0385 & $0.0767 *$ \\
\hline Risk profile $(R I S K)$ & -0.0045 & $0.0805^{*}$ & -0.0032 & 0.1069 \\
\hline Efficiency of bank production $(E F F)$ & 0.0081 & $0.0462 *$ & 0.0143 & $0.0443^{* *}$ \\
\hline Scale effects (TASSETS) & 0.0000 & $0.0564 *$ & 0.0000 & $0.0432 * *$ \\
\hline Degree of competition (COMP) & -0.0018 & $0.0777^{*}$ & 0.9517 & $0.0378^{* *}$ \\
\hline Rule of law $(R O L)$ & -0.0092 & $0.0409^{* *}$ & -0.0102 & $0.0770^{*}$ \\
\hline Control of corruption (CORR) & -0.0163 & $0.0002 * * *$ & -0.0119 & $0.0148 * *$ \\
\hline $\operatorname{Tax}(T A X)$ & -0.0001 & $0.0278 * *$ & -0.0001 & $0.0257 * *$ \\
\hline
\end{tabular}

\section{Panel B: Diagnostics}

Equilibrium test

(Wald test for $\mathrm{H}=0$ )

Sargan Test

Hausman Test

$\operatorname{AR}(1)$

$\operatorname{AR}(2)$
Bangladesh $\mathrm{H}=0.2912(p$-value $=0.4878) ;$ India $\mathrm{H}=0.8897$

$(p$-value $=0.3048) ;$ Pakistan $\mathrm{H}=0.7988(p$-value $=0.4675) ;$ Sri

Lanka $\mathrm{H}=0.2176(p$-value $=0.5975)$

$X^{2}(106)=274.61$

$X^{2}(9)=35$

$\mathrm{z}=-13.79$ (p-value 0.0001$)$

$\mathrm{z}=1.52(\mathrm{p}$-value $=0.13)$

$* * *, * *$ and $*$ signify statistical significance at 1,5 and 10 percent respectively.

Consistent with prior evidence, the ratio of total loans to deposits and short-term funds (RISK variable in Equation 3) is negatively associated with bank profitability (weakly significant at 10 percent level in Model 1). This indicates that higher levels of loans to deposits and short-term funds exert downward pressure on bank profitability due to higher levels of non-performing assets and increased liquidity costs. Likewise, the efficiency of bank production ( $E F F$ variable in Equation 3 ) is found to be significantly positively related to bank profitability. This is in line with conventional wisdom that improved efficiency and productivity growth positively affect bank profits.

With regard to scale effects (TASSETS in Equation 3), bank size is found to be positively related to profitability. This positive association indicates that as South Asian banks increase their size, their profitability also increases perhaps due to increased economies of scale. Moreover, larger banks can achieve greater product and loan diversification and so lower their risk profiles. Hence, required rate of return becomes lower which reduces their costs, generating higher profits. Similarly, large banks may also be able to exert greater market power through stronger brand image or implicit regulatory (too-big-to-fail) protection. Abnormal profits obtained through its exercise in wholesale or capital markets may also contribute to a positive size-profitability relationship. 
The level of competition (COMP in Equation 3) is proxied by the $H$ statistic (in Model 1 ) and the $H H I$ (in Model 2). A basic assumption of the $P R$ Model used to compute the $H$ statistics is that firm level revenue behaviour is consistent with market equilibrium conditions. To that end, following Bikker and Haaf (2002), an equilibrium test was conducted before estimating Equation 3 to determine, for each country, whether or not the equilibrium assumption of the PR model is violated. The test statistics, reported in Panel B of Table 5, are not statistically significant at 90 percent level. This indicates that input prices in each banking market are not correlated with industry returns: meaning, the equilibrium assumption of the PR model holds and the computed $H$ statistics can be interpreted rationally.

As anticipated, increasing competition among South Asian banks (captured by higher values for the $H$ statistic, in Model 1) exerts negative pressure on bank profitability (Table 5, Panel A). This is so because increasingly banks compete on price and incur expenses to counter competitors' strategic moves. Interestingly, in Model 2, higher values of the HHI are associated with higher profitability. This means that those South Asian banks operating in relatively concentrated markets (characterised by higher $H H I$ values) extract economic rents and higher profits. Overall, the received wisdom is that even though increasing competition (arguably driven by on-going deregulation and liberalisation of the financial services industries) exerts negative pressure on bank profitability in these South Asian countries, high levels of industry concentration still allows 'large' banks to earn higher profits. This observation is consistent with the proposition that competition can prevail even in highly concentrated markets. Moreover, the higher profits earned by these banks (despite increasing competition) may reflect the practice of product differentiation as found by Perera, Skully and Wickremanayake (2007).

In the South Asian banking markets low quality rule of law (represented by $R O L$ in Equation 3)) and lack of effective corruption control (represented by CORR in Equation 3) are found to be significantly influencing bank profitability. The results indicate that slack legal systems in the South Asian countries (leading to inferior contract enforcement) positively affect bank profits as banks probably require higher risk premiums on their loan contracts. Moreover, arguably, banks may exploit lack of effective corruption controls to create and maintain 'profitable' relationships which otherwise would not have existed.

The result for $T A X$ variable is not consistent with expectations as the tax rate is found to have significantly negative impact on bank profitability. This indicates that South Asian banks must bear most of their tax costs and are unable to pass these onto their customers. The vector of time dummies utilised to account for time-varying omitted influences reveal that during 1997-1999 Asian financial crisis period bank profitability declined. This is consistent with the decline in earning asset growth and incline in substantial provision for non-performing assets during that period.

We also experimented with three other macroeconomic variables: long-term interest rate, inflation rate and real output growth. These three variables were found to be highly correlated with each other and the bank size variable included in Equation 3. We acknowledge that bank size is more relevant in controlling for uneven distribution in firm size in the sample and 
hence included. It is argued that the inclusion of the vector of time dummies can capture, partially at least, time-varying effects of economic life cycle.

\section{Conclusion}

This paper investigated the bank-specific and external determinants of South Asian bank profitability. The sample consisted of 119 commercial banks with 1,539 bank-year observations. A single-equation, dynamic panel data procedure was employed to accommodate explicit measures of production efficiency, industry competition, profit persistence and country-specific differences in governance.

The findings reveal that well-capitalised low risk banks and those with relatively more efficient production processes are more profitable. South Asian banks also seem to experience economies of scale as bank size is positively associated with profitability. With regard to competition, even though increasing competition (arguably driven by on-going deregulation and liberalisation of the financial services industries) exerts negative pressure on bank profitability, high levels of industry concentration still allows banks to earn higher profits. This observation is consistent with the proposition that competition can prevail even in highly concentrated markets. Moreover, the higher profits earned by these banks (despite increasing competition) may also be due to the practice of product differentiation. The results also indicate that slack legal systems in the South Asian countries (leading to inferior contract enforcement) positively affect bank profits as banks probably require higher risk premiums on their loan contracts. Moreover, arguably, banks may be able to exploit lack of effective corruption controls to create and maintain 'profitable' relationships which otherwise might not have existed.

The findings have important implications to regulators, bankers and bank shareholders. For regulators, their policy formulation and implementation can be streamlined by directing scarce regulatory resources to focus on external factors that restrict profitable and stable banking systems (such as mergers and acquisitions that increase industry concentration). At the same time, regulators and authorities should scrutinize banking practices in these countries as there is a positive association between low quality rule of law/corruption controls and bank profitability. For bankers, the findings should help to identify the key drivers (both internal and external) to achieve stable profits which in turn lead to sustainability and stability at the firm level. This is important due to the increased competition through globalization of banking and foreign bank entry into the South Asian financial markets. For shareholders, it helps to assess how varying bank characteristics can alter the quality of their returns and control for those factors that can adversely affect the bank profits.

This study, however, suffers from some limitations. With regard to sample composition, as almost all foreign-owned banks operating in South Asia publish only their world-wide consolidated reports, it is not possible to include foreign-owned banks even as a control sample. Due to resource constraints and data limitations, we could also not include some other bank-specific and country-specific factors that might also impact on bank profitability (e.g. off balance sheet activities, a composite measure of deregulation and financial liberalisation over the years etc.). Moreover, annual bank-specific data is used as higher 
frequency data (e.g. weekly or monthly data) was not available. Finally, due to lack of detailed information on different bank products, it could not be identified whether the use of different products (or product mixes) might affect bank profitability.

\section{References}

Arellano, M., \& Bover, O. (1995). Another look at the instrumental variables: estimation of error-component models. Journal of Econometrics, 68, 29-51. http://dx.doi.org/10.1016/0304-4076(94)01642-D

Arellano, M., \& Bond, S. (1991). Some tests of specification for panel data: Monte Carlo evidence and an application to employment equations. Review of Economic Studies, 58, 277-297. http://dx.doi.org/10.2307/2297968

Athanasoglou, P., Brissimis, S., \& Delis, M. (2008). Bank-specific, industry-specific and macroeconomic determinants of bank profitability. Journal of International Financial Markets, Institutions \& Money, 18, 121-136. http://dx.doi.org/10.1016/j.intfin.2006.07.001

Baltagi, B. (2001). Econometric analysis of panel data. John Wiley \& Sons, Chichester. Available at http://au.wiley.com/WileyCDA/WileyTitle/productCd-EHEP000952.html

Bangladesh Bank. (2009). Annual report. Bangladesh Bank, Dhaka. Available at http://www.bangladesh-bank.org/pub/annual/anreport/ar0910/index0910.php

Berger, A., \& Humphrey, D. (1997). Efficiency of financial institutions: international survey and directions for future research. European Journal of Economic Research, 98, 175-212. http://dx.doi.org/10.1016/S0377-2217(96)00342-6

Berger, A., Hancock, D., \& Humphrey, D. (1993). Bank efficiency derived from the profit function. Journal of Banking and Finance, 17, 317-347. http://dx.doi.org/10.1016/0378-4266(93)90035-C

Berger, A., Bonime. S., Covitz, D., \& Hancock, D. (2000). Why are bank profits so persistent? the roles of product market competition, informational opacity, and regional/macroeconomic shocks. Journal of Banking and Finance, 24, 1203-1235. http://dx.doi.org/10.1016/S0378-4266(99)00124-7

Bikker, J., \& Haaf, K. (2002). Measures of competition and concentration: a review of the literature. Economic \& Financial Modelling, 9, 53-98. doi:N/A

Central Bank of Sri Lanka. (2009). Financial System Stability Review. Central Bank of Sri Lanka, Colombo. Available at http://www.cbsl.gov.lk/pics_n_docs/10_pub/_docs/efr/financial_system_stability_review/fssr _2009.pdf

Demirguc-Kunt, A., \& Huizinga, H. (1999). Determinants of commercial bank interest margins and profitability: some international evidence. World Bank Economic Review, 13, 379-408. http://dx.doi.org/10.1093/wber/13.2.379

Gilbert, A. (1984). Bank market structure and competition: a survey. Journal of Money, 
Credit, and Banking, 16, 617-645. http://dx.doi.org/10.2307/1992096

Goddard, J., Molyneux P., \& Wilson, J. (2004). Dynamics of growth and profitability in banking. Journal of Money, Credit and Banking, 36, 1069-1022. http://dx.doi.org/10.1353/mcb.2005.0015

Kaufmann, D., Kraay, A., \& Mastruzzi, A. (2007). Governance Matters VI: Aggregate and Individual Governance Indicators, The World Bank, Washington DC. Available at https://openknowledge.worldbank.org/bitstream/handle/10986/7473/wps4280.txt?sequence=2

Kosmidou, K. (2008). The determinants of banks' profits in Greece during the period of EU financial integration. Managerial Finance, 34, 146-159. http://dx.doi.org/10.1108/03074350810848036

Kosmidou, K., Pasiouras, F., \& Tsaklanganos, A. (2007). Domestic and multinational determinants of foreign bank profits: the case of Greek banks operating abroad. Journal of Multinational Financial Management, $\quad 17, \quad$ 1-15. http://dx.doi.org/10.1016/j.mulfin.2006.02.002

Maddala, G., \& Wu, S. (1999). A comparative study of unit root tests with panel data and a new simple test. Oxford Bulletin of Economics and Statistics, 61, 631-652. http://dx.doi.org/10.1111/1468-0084.0610s1631

Miller, S., \& Noulas, A. (1997). Portfolio mix and large-bank profitability in the USA. Applied Economics, 29, 502-512. http://dx.doi.org/10.1080/000368497326994

Molyneux, P., Thornton, J. (1992). Determinants of European bank profitability: a note. Journal of Banking and Finance, 16, 1173-1178. http://dx.doi.org/10.1016/0378-4266(92)90065-8

Panzar, J., \& Rosse, J. (1987). Testing for monopoly equilibrium. Journal of Industrial Economics, 35, 443-56. http://dx.doi.org/10.2307/2098582

Pasiouras, F., \& Kosmidou, K. (2007). Factors influencing the profitability of domestic and foreign commercial banks in the European Union. Research in International Business and Finance, 21, 222-237. http://dx.doi.org/10.1016/j.ribaf.2006.03.007

Perera, S., Skully, M., \& Wickramanayake, J. (2006). Competition and structure of South Asian banking: a revenue behaviour approach. Applied Financial Economics, 16, 789-801. http://dx.doi.org/10.1080/09603100600687461

Perera, S., Skully, M., \& Wickramanayake, J. (2007). Cost efficiency in South Asian banking: the impact of bank size, state ownership and stock exchange listings. International Review of Finance, 7, 35-60. http://dx.doi.org/10.1111/j.1468-2443.2007.00067.x 